\title{
Palladium(II) complexes containing a bulky pyridinyl $N$-heterocyclic carbene ligand: Preparation and reactivity
}

\author{
Chao-Yu Wang, Yi-Hong Liu, Shei-Ming Peng, Jwu-Ting Chen, Shiuh-Tzung Liu * \\ Department of Chemistry, National Taiwan University, Taipei 106, Taiwan, ROC
}

Received 11 April 2007; received in revised form 27 May 2007; accepted 5 June 2007

Available online 15 June 2007

\begin{abstract}

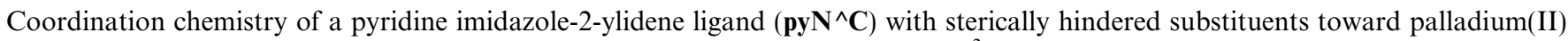
metal ions has been investigated. The palladium carbene complex $\left[\left(C\right.\right.$-pyN^ $\left.\mathbf{N}^{\wedge} \mathbf{C}\right) \mathrm{Pd}\left(\eta^{3}\right.$-allyl $\left.) \mathrm{Cl}\right](\mathbf{3})$ is prepared via the transmetallation from the corresponding silver carbene complexes with $\left[\mathrm{ClPd}\left(\eta^{3} \text {-allyl }\right)\right]_{2}$. Upon the abstraction of chloride, coordination of pyridinylnitrogen becomes feasible to form $\left[C, N-\left(\mathbf{p y} \mathbf{N}^{\wedge} \mathbf{C}\right) \operatorname{Pd}\left(\eta^{3}\right.\right.$-allyl $\left.)\right]\left(\mathrm{BF}_{4}\right)(\mathbf{4})$. Ligand substitution reaction of 4 with triphenylphosphine results in the formation of $\left[\left(C\right.\right.$-pyN^ $\left.\mathbf{N}^{\wedge} \mathbf{C}\right) \operatorname{Pd}\left(\mathrm{PPh}_{3}\right)\left(\eta^{3}\right.$-allyl $\left.\left.)\right]\left(\mathrm{BF}_{4}\right)\right]$, which the pyridinyl-nitrogen donor is substituted by the phosphine. This palladium complex appears to be base sensitive. Treatment of $\mathbf{4}$ with $t$-butoxide causes the decomposition to yield the metal nano-particles. Furthermore, de-complexation of $\mathbf{4}$ takes place under hydrogen atmosphere to generate the carbene precursor, 1-(6-mesityl-2-picolyl)-3mesitylimidazolium salt. Nevertheless, the palladium complex 4 shows good catalytic activity on the Suzuki-Miyaura and MizorokiHeck reactions.
\end{abstract}

(C) 2007 Elsevier B.V. All rights reserved.

Keywords: Carbene; Palladium; Catalysis; Nano-particle; Coupling reaction

\section{Introduction}

The use of diaminocarbenes (NHC) as ligands on stabilization of transition metal ions for catalysis has been received much attention [1-11]. These carbene donors are generally considered as an important class of donors with strong basicity and good $\sigma$-donating properties. Thus, transition metal complexes containing such carbene moieties are thermally more stable than those with phosphine species [2e].

Regarding the chelating carbene ligands, quite a few hetero-functionalized diaminocarbene ligands are known [610]. In our previous works, we also reported the study of a bidentate ligand with sterically hindered groups on both

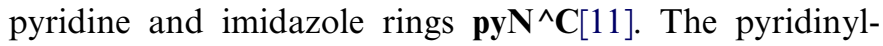
nitrogen donor of $\left[\left(C, N\right.\right.$-py $\left.\left.\mathbf{N}^{\wedge} \mathbf{C}\right) \mathrm{Rh}(\mathrm{COD})\right] \mathrm{BF}_{4}$ was found to be labile and could be replaced by various donors such as phosphine, azide and halides. Continuing this trend,

\footnotetext{
${ }^{*}$ Corresponding author. Tel.: +88622366 0352; fax: +8862 23636359 .

E-mail address: stliu@ntu.edu.tw (S.-T. Liu).
}

we pursue to investigate the coordination of $\mathbf{p y} \mathbf{N}^{\wedge} \mathbf{C}$ toward palladium ions and their activities.

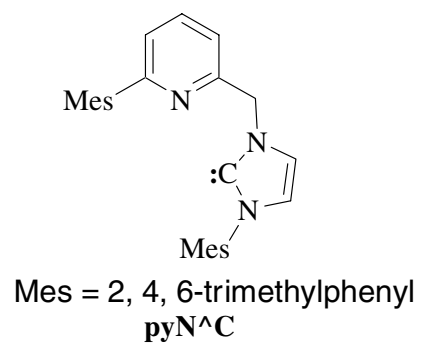

\section{Results and discussion}

\subsection{Synthesis of $\pi$-allylpalladium carbene complexes}

The synthetic approach leading to the desired palladium complex 4 is shown in Scheme 1. Conversion of the pyridinyl-imidazolium salt $\mathbf{1}$ into the silver carbene complex 


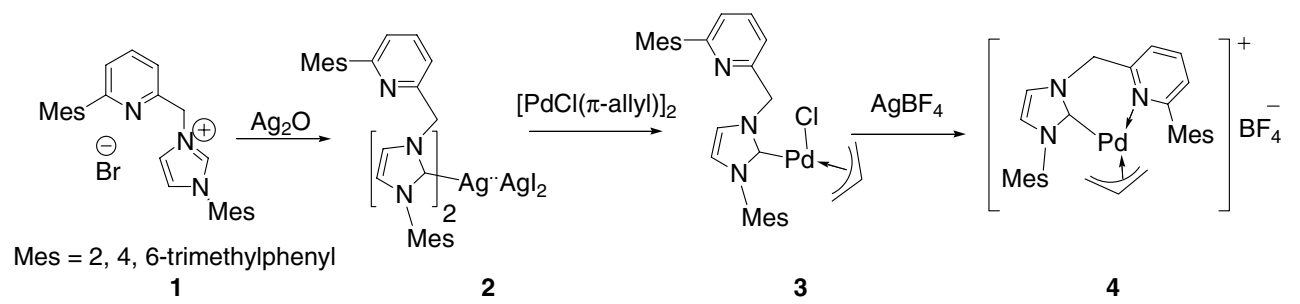

Scheme 1. Preparation of the palladium carbene complex.

$\left[C-\left(\mathbf{p y N} \mathbf{N}^{\wedge} \mathbf{C}\right)_{2} \mathrm{AgAgI}_{2}\right]$ (2) was achieved via the method previously reported [11]. Treatment of $\mathbf{2}$ with $[\mathrm{PdCl}(\pi \text {-allyl })]_{2}$ caused the carbene moiety transfer from $\mathrm{Ag}$ to $\mathrm{Pd}$ to yield the palladium carbene complex 3. Abstraction of chloride from complex 3 via the addition of silver ion readily assisted the coordination of pyridinyl-nitrogen to the palladium center, resulting in the formation of $[\mathrm{C}, \mathrm{N}-$ $\left(\mathbf{p y N} \mathbf{N}^{\wedge} \mathbf{C}\right) \operatorname{Pd}(\pi$-allyl) $] \mathrm{BF}_{4}(4)$.

The structures of palladium complexes were determined by both spectroscopic and elemental analyses and the complex 4 was further confirmed by its single crystal structural determination. ${ }^{13} \mathrm{C}$ NMR data for the coordinating carbene carbons appear at $\delta 179.7$ for $\mathbf{3}$ and 176.3 for $\mathbf{4}$, respectively, suggesting the formation of the palladium carbon bond. These signals are all in the typical range for $\mathrm{Pd}-\mathrm{C}_{\text {(carbene) }}$ observed for the analogues [12]. The ${ }^{1} \mathrm{H}$ NMR shifts corresponding to the proton of pyridine ring on $\mathbf{3}$ are similar to those of the silver complexes (Table 1), indicating that the pyridinyl-nitrogen donor remains un-coordinated, but not for 4 . A significant coordination chemical shifts appear for those hydrogen atoms of the pyridine ring on 4, suggesting the chelation of $\mathbf{p y}^{\wedge} \mathbf{N}^{\wedge} \mathbf{C}$ toward the palladium center. The detail coordination sphere around the metal center of 4 was confirmed by the X-ray crystal structural analysis.

Fig. 1 displays the ORTEP plot of the cationic portion of 4 . Considering the allyl being a bidentate, the metal center in $\mathbf{4}$ displays a square planar geometry. Bond length of $\mathrm{Pd}-\mathrm{C}_{\text {(carbene) }}[2.052(4) \AA]$ is in the normal range as compared to those of the related palladium species (Scheme 2

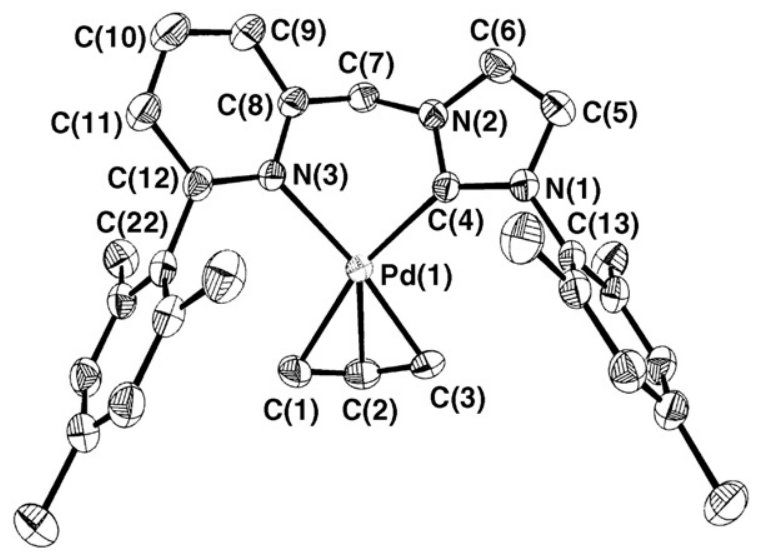

Fig. 1. ORTEP plot of cationic portion of 4 (30\% probability ellipsoids).

and Table 2). Notable feature of this structure is the angle of $\mathrm{Pd}(1)-\mathrm{C}(4)-\mathrm{N}(1)\left[136.1(3)^{\circ}\right]$ away from $120^{\circ}$, presumably due to the constrain raised from the chelation of $\mathbf{P y N}^{\wedge} \mathbf{C}$. The bisect angle of imidazole ring and rhodium coordination plane is $33.5^{\circ}$, revealing the non-coplanar nature. Due to the trans influence, bond length of $\operatorname{Pd}(1)-$ $\mathrm{C}(1)[2.222(5) \AA]$ is slightly longer than that of $\mathrm{Pd}(1)-$ C(3) $[2.095(4) \AA]$ by about $0.12 \AA$.

Comparison of structural variation among a series of $[(\pi$-allyl)Pd(NHC)] complexes is summarized in Table 2. The general trends on bond lengths and bond angles of $\mathbf{4}$ are quite similar to those of known species as the listed (Scheme 2) except the angle of $\mathrm{X}-\mathrm{Pd}-\mathrm{C}_{\text {(carbene) }}$. Due to the chelation effect, the bite angle of $4[\mathrm{~N}(3)-\mathrm{Pd}(1)-\mathrm{C}(4)$ $88.8(1)^{\circ}$ ] is smaller than $90^{\circ}$.

Table 1

Selected spectral data for metal carbene complexes

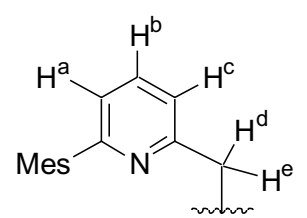

\begin{tabular}{llllll}
\hline Complex & ${ }^{1} \mathrm{H}$ NMR & & & \\
\cline { 2 - 5 } & $\mathrm{H}^{\mathrm{a}}$ & $\mathrm{H}^{\mathrm{b}}$ & $\mathrm{H}^{\mathrm{c}}$ & $\mathrm{H}^{\mathrm{d}}$ and $\mathrm{H}^{\mathrm{e}}$ & ${ }^{13} \mathrm{C}$ NMR \\
\hline $\mathbf{2}^{\mathrm{a}}$ & $7.45(\mathrm{~d}, J=8.0)$ & $7.74(\mathrm{dd}, J=8.0,8.0)$ & $7.16(\mathrm{~d}, J=8.0)$ & 5.51 & 183.5 \\
$\mathbf{3}$ & $7.90(\mathrm{~d}, J=7.6)$ & $7.79(\mathrm{dd}, J=7.6,7.6)$ & $7.18(\mathrm{~d}, J=7.6)$ & $5.91(\mathrm{~d}, J=14.8) 5.75(\mathrm{~d}, J=14.8)$ & 179.7 \\
$\mathbf{4}$ & $8.20(\mathrm{dd}, J=7.6,1.2)$ & $8.03(\mathrm{dd}, J=7.6,7.6)$ & $7.34(\mathrm{dd}, J=7.6,1.2)$ & $5.81(\mathrm{~d}, J=14.4) 5.60(\mathrm{br})$ & 176.3 \\
\hline
\end{tabular}

${ }^{\text {a }}$ Ref. [11]. 


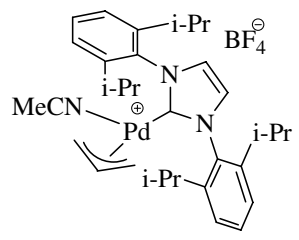

I

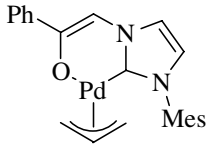

II

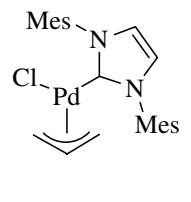

III
Scheme 2. Representative $[(\pi$-allyl $) \mathrm{Pd}(\mathrm{NHC})]$ species.

Table 2

Comparison of selected bond distances $(\AA)$ and bond angles $\left(^{\circ}\right)$ of palladium complexes

\begin{tabular}{lcccc}
\hline Complex & $\mathbf{4}(\mathrm{X}=\mathrm{N})$ & $\mathbf{I}(\mathrm{X}=\mathrm{N})^{\mathrm{a}}$ & II $(\mathrm{X}=\mathrm{O})^{\mathrm{b}}$ & III $(\mathrm{X}=\mathrm{Cl})^{\mathrm{c}}$ \\
\hline Pd-C (carbene) & $2.052(4)$ & $2.066(2)$ & $2.022(4)$ & 2.029 \\
Pd-X & $2.193(3)$ & $2.086(2)$ & $2.062(3)$ & 2.380 \\
Pd-allyl & $2.222(5)$ & $2.199(3)$ & $2.204(4)$ & 2.204 \\
& $2.152(4)$ & $2.150(2)$ & $2.133(5)$ & 2.131 \\
& $2.095(4)$ & $2.081(2)$ & $2.113(4)$ & 2.113 \\
& & & & \\
X-Pd-C & & & &
\end{tabular}

a Ref. [13].

b Ref. [14].

c Ref. [15].

\subsection{Reactivity of $\pi$-allylpalladium carbene complexes}

\subsubsection{Triphenylphosphine}

Treatment of $\mathbf{4}$ with triphenylphosphine in dichloromethane at ambient temperature resulted in the de-coordination of pyridinyl-nitrogen to yield the phosphine-substituted complex (Scheme 3), indicating that the chelation does not enhance its donating ability. This phosphine complex exists in two isomers, $\mathbf{5} \mathbf{a}$ and $\mathbf{5 b}$, due to the stereo-orientation of $\pi$-allyl group relative to the un-symmetrical carbene ligand. Both 5a and 5b show significant differences in ${ }^{1} \mathrm{H}$ and ${ }^{31} \mathrm{P}$ NMR shifts. However, we were not able to isolate either one in pure form due to the rapid interconversion of each other.

The ratio of $\mathbf{5 a}$ to $\mathbf{5 b}$ is temperature dependent and was estimated by the ${ }^{31} \mathrm{P}$ NMR peak integration (Fig. 2). It appears that $\mathbf{5 b}$ is slightly more stable than $\mathbf{5 a}$ presumably due to the steric repulsion between the $\pi$-allyl group and the mesityl substituent of carbene moiety. The equilibrium constants at various temperatures are summarized in

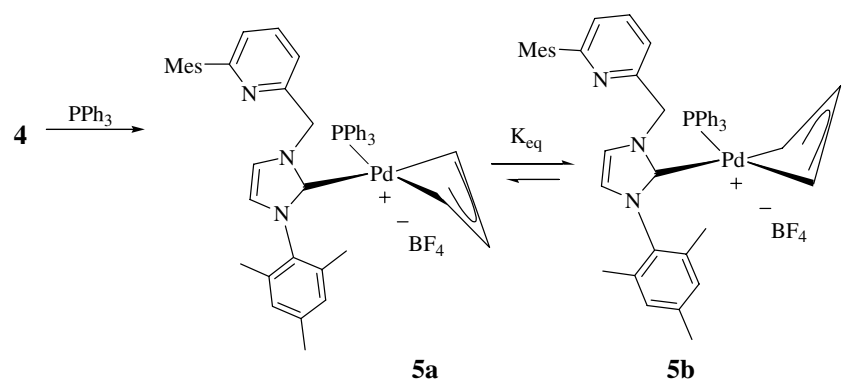

Scheme 3 .

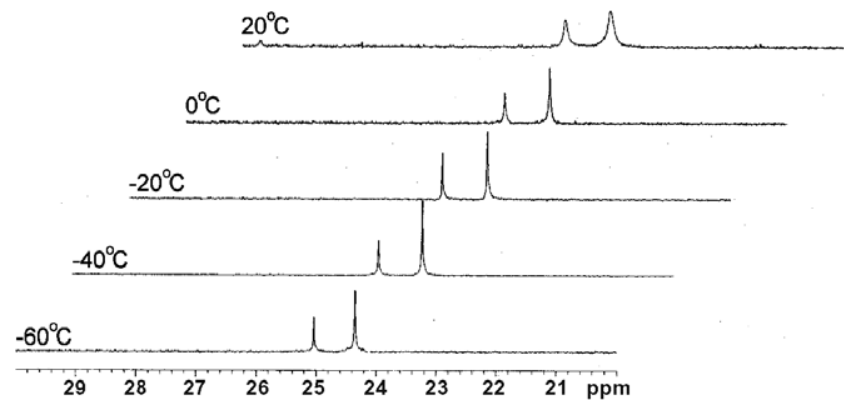

Fig. 2. ${ }^{31} \mathrm{P}$ NMR spectra of $\mathbf{5 a}$ and $\mathbf{5 b}$ under various temperature.

Table 3. The free energy of this interconversion is derived to be $1.4 \pm 0.2 \mathrm{~kJ} / \mathrm{mol}$, showing a very small energy difference between two species.

Complex $\mathbf{5}$ is fairly stable under nitrogen atmosphere without any change for a week, but it slowly decomposed in the presence of air. By monitoring the sample in a $\mathrm{CDCl}_{3}$ solution, 5 was slowly transferred into $\mathbf{4}$ accompanied with the formation of triphenylphosphine oxide (Eq. (1)). After stirring for $72 \mathrm{~h}$, this solution of $\mathbf{5}$ was completely converted into 4. Apparently, the dissociated phosphine is readily oxidized by the oxygen to yield its oxide, and the dissociation of phosphine allows the $\mathbf{p y N}^{\wedge} \mathbf{C}$ ligand to regain the chelation.

$\mathbf{5 a}+\mathbf{5 b} \stackrel{\text { air }}{\longrightarrow} \mathbf{4}+\mathrm{O}=\mathrm{PPh}_{3}$

\subsubsection{Alkoxide}

It has been studied by Nolan and coworkers that reaction of a carbene allylpalladium complex with $t$-butoxide in the presence of phosphine would yield a divalent palladium species (Eq. (2)) [15]. It is clear that the nucleophilic attack of alkoxide toward coordinating $\pi$-allyl ligand resulted in the formation $\operatorname{Pd}(0)$ species.

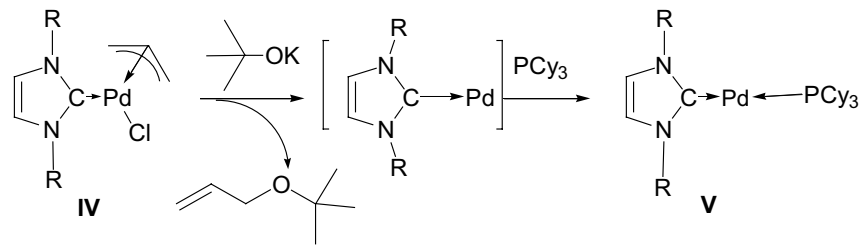

Under the similar conditions, complex 3 reacted with $t$-butoxide in the presence of tricyclohexylphosphine in benzene to give a solution of palladium nano-particles, instead of the production of palladium carbene phosphine complexes. In this reaction, we did not observe any formation of $t$-butyl allyl ether. ${ }^{31} \mathrm{P} \mathrm{NMR}$ spectrum of this solution appears one signal at $\delta$ 47.2, which is in

Table 3

Equilibrium constants between $\mathbf{5 a}$ and $\mathbf{5} \mathbf{b}^{\mathrm{a}}$

\begin{tabular}{lrrrrc}
\hline$T(\mathrm{~K})$ & 213 & 233 & 253 & 273 & 293 \\
$\mathrm{~K}_{\text {eq. }}$ & 2.19 & 2.07 & 1.97 & 1.82 & 1.73 \\
\hline
\end{tabular}

${ }^{\mathrm{a}}$ In $\mathrm{D}_{2} \mathrm{Cl}_{2}$. 
agreement with the coordinating tricyclophosphine on the palladium nano-particles [16]. With the observation of TEM (Fig. 3a), the sizes of particles are ranging from 2 to $10 \mathrm{~nm}$, indicating these particles not uniformly formed. From EDX analysis showed that phosphorus, potassium and chlorine elements are presented on the all area of the sample. This palladium nano-particle solution appeared to be stable under nitrogen atmosphere for weeks. Apparently, the resulting nano-particles are stabilized by the phosphines. Similarly, complex 4 also decomposed in the presence of $t$-butoxide to form the palladium nano-particles with the size in 2-4 nm (Fig. 3b).

Apparently, complexes $\mathbf{3}$ and $\mathbf{4}$ behave quite different from those related complexes such as IV. Unlike the formation of the carbene phosphine complex $\mathbf{V}$ (Eq. (2)), reaction of $\mathbf{3}$ or $\mathbf{4}$ with $t$-butoxide readily caused the decomposition to yield the palladium particles. This is presumably due to the presence of benzylic protons in this structure. It has been demonstrated by Cavell's and other groups that deprotonation of the imidazolium salt $\mathbf{1}$ with a strong base did not produce the corresponding carbene due to the interference of the deprotonation of benzylic methylene protons [6].

\subsubsection{Hydrogen}

Under atmospheric pressure of hydrogen gas, both 3 and 4 are stable at room temperature, without any decomposition for $48 \mathrm{~h}$. However, complex 4 slowly decomposed at $50{ }^{\circ} \mathrm{C}$ to yield the corresponding imidazolium salt and palladium black (Eq. (3)). This is presumably due to the oxidative addition of hydrogen to the metal ion followed by the reductive elimination of propene and ligand. In fact, the addition of $\mathrm{HBF}_{4}$ to a solution of $\mathbf{3}$ or $\mathbf{4}$ in $\mathrm{CDCl}_{3}$ also caused the decomposition to yield the imidazolium salt.
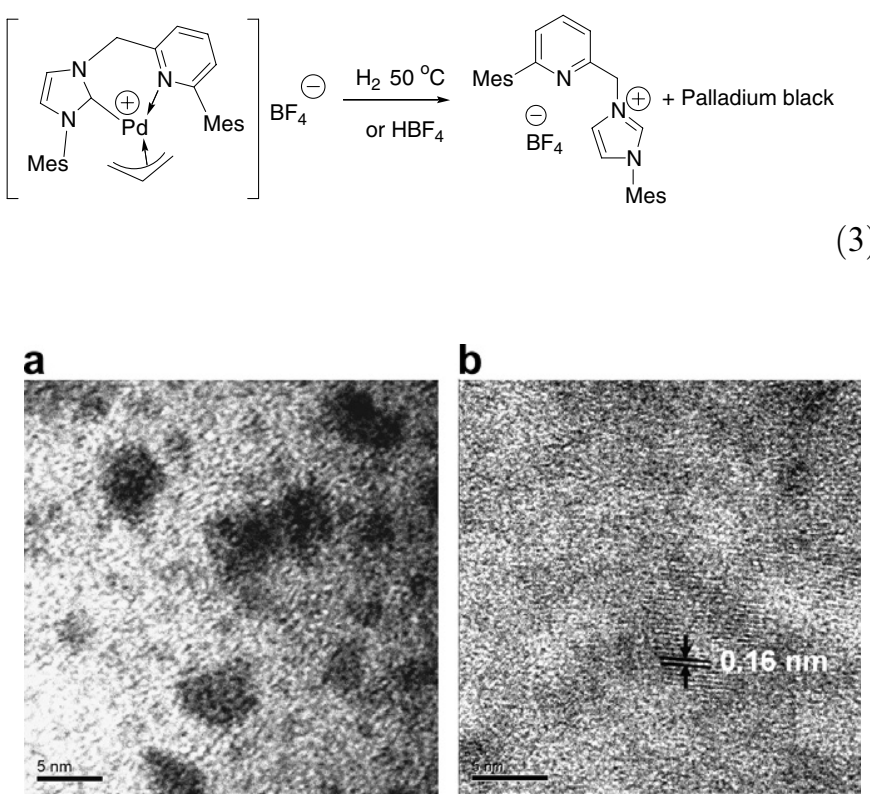

Fig. 3. TEM photography of Pd nano-particles (a) from $\mathbf{3}$ and (b) from 4.

\subsection{Catalysis}

\subsubsection{Suzuki-Miyaura coupling}

The palladium carbene complex $\mathbf{4}$ was subjected to evaluate its catalytic activity on the coupling reaction of phenylboronic acid with aryl halides. In a typical experiment for the reaction, aryl halide, phenylboronic acid and base in a ratio of 1:1.1:2 were placed in the flask, followed by the addition of the solvent and the catalyst. The mixture was heated to $60{ }^{\circ} \mathrm{C}$ for a certain period. The organic product was isolated by extraction and then analyzed by both GC and ${ }^{1} \mathrm{H}$ NMR spectroscopy. Results are summarized in Table 4.

The initial screen on solvents and various bases were performed using 4 as the catalyst precursor (Table 4, entries 1-6). It appeared that a mixed solvent of water/toluene gave better results than any other organic solvents. In case of bases, all carbonate salts and lithium hydroxide provided excellent results. It is noticed that the reaction needs to carry out under atmosphere of nitrogen. In other words, the catalyst is quite sensitive to air.

We then found that the addition of triphenylphosphine to the catalytic system readily increased the reaction yield up to $90 \%$ (Table 4 , entry 7 ). The phosphine presumably underwent the ligand substitution toward metal center as illustrated in the previous section. Indeed, the use of $\mathbf{5}$ as the catalyst for this coupling does provide the same result. The beneficial effect of phosphine on the catalysis was also applicable to reduce the amount of catalysts. With the molar ratio of $[$ substrate $] /[\mathrm{Pd}]=2000$, the addition of phosphine can improve the yield of the coupling product (Table 4, entry 8).

Under the optimized reaction conditions, the catalytic activities of the palladium complexes toward aryl bromide appear to be excellent, but poor for a steric hindered aryl bromide (entry 12). Similar to other catalytic systems, this palladium complex shows less active toward aryl chlorides, with less yields and longer reaction times (entries 16 and 17). Nevertheless, the palladium complexes prepared in this work behave good catalytic activity on the Suzuki-Miyaura coupling reaction.

\subsubsection{Mizoroki-Heck coupling}

Palladium carbene complexes have been shown to be effectively active on the catalysis in a wide range of coupling reactions. On the basis of the palladium catalyzed Suzuki-Miyaura coupling described above, we found it appropriate to test them in Mizoroki-Heck reaction. This coupling reaction is an efficient way to prepare styrene derivatives, which are important chemicals for many applications. On the screen of solvents and bases, we established that NMP and diisopropylamine are the best combination for this coupling reaction with the use of $\mathbf{4}$ as the catalyst (Table 5). Similar to the finding in the Suzuki-Miyaura reaction, the addition of phosphine undoubtedly increases the activity of catalyst. As shown from the data in Table 5 , most aryl bromides as substrates give excellent yields except the indole derivative. 
Table 4

Coupling of arylhalides with arylboronic acid catalyzed by complex $\mathbf{4}^{\mathrm{a}}$

\begin{tabular}{|c|c|c|c|c|c|c|c|}
\hline Entry & Ar-X & $\mathrm{ArB}(\mathrm{OH})_{2}$ & Catalyst $\left(\mathrm{mol}^{\%} \%\right)$ & Base & Solvent & Yield $^{\mathrm{b}}$ & $\mathrm{TOF}^{\mathrm{c}}$ \\
\hline 1 & 4- $\mathrm{BrC}_{6} \mathrm{H}_{4} \mathrm{CHO}$ & $\mathrm{C}_{6} \mathrm{H}_{5} \mathrm{~B}(\mathrm{OH})_{2}$ & 0.5 & $\mathrm{Na}_{2} \mathrm{CO}_{3}(0.38 \mathrm{~mol})$ & DMF & 0 & 0 \\
\hline 2 & 4- $\mathrm{BrC}_{6} \mathrm{H}_{4} \mathrm{CHO}$ & $\mathrm{C}_{6} \mathrm{H}_{5} \mathrm{~B}(\mathrm{OH})_{2}$ & 0.5 & $\mathrm{Na}_{2} \mathrm{CO}_{3}(0.38 \mathrm{~mol})$ & IPA & 0 & 0 \\
\hline 3 & $4-\mathrm{BrC}_{6} \mathrm{H}_{4} \mathrm{CHO}$ & $\mathrm{C}_{6} \mathrm{H}_{5} \mathrm{~B}(\mathrm{OH})_{2}$ & 0.5 & $\mathrm{Na}_{2} \mathrm{CO}_{3}(0.38 \mathrm{~mol})$ & Toluene $/ \mathrm{H}_{2} \mathrm{O}$ & 79 & 26 \\
\hline 4 & 4- $\mathrm{BrC}_{6} \mathrm{H}_{4} \mathrm{CHO}$ & $\mathrm{C}_{6} \mathrm{H}_{5} \mathrm{~B}(\mathrm{OH})_{2}$ & 0.5 & $\mathrm{~K}_{2} \mathrm{CO}_{3}(0.46 \mathrm{~mol})$ & Toluene/ $/ \mathrm{H}_{2} \mathrm{O}$ & 88 & 29 \\
\hline 5 & 4- $\mathrm{BrC}_{6} \mathrm{H}_{4} \mathrm{CHO}$ & $\mathrm{C}_{6} \mathrm{H}_{5} \mathrm{~B}(\mathrm{OH})_{2}$ & 0.5 & $\mathrm{LiOH}$ (1 mmol) & Toluene $/ \mathrm{H}_{2} \mathrm{O}$ & 99 & 33 \\
\hline 6 & $4-\mathrm{BrC}_{6} \mathrm{H}_{4} \mathrm{CHO}$ & $\mathrm{C}_{6} \mathrm{H}_{5} \mathrm{~B}(\mathrm{OH})_{2}$ & 0.5 & $\mathrm{NaOAc}(0.46 \mathrm{mmol})$ & Toluene $/ \mathrm{H}_{2} \mathrm{O}$ & 41 & 14 \\
\hline $7^{\mathrm{d}}$ & 4- $\mathrm{BrC}_{6} \mathrm{H}_{4} \mathrm{CHO}$ & $\mathrm{C}_{6} \mathrm{H}_{5} \mathrm{~B}(\mathrm{OH})_{2}$ & 0.5 & $\mathrm{Na}_{2} \mathrm{CO}_{3}(0.38 \mathrm{~mol})$ & Toluene $/ \mathrm{H}_{2} \mathrm{O}$ & 90 & 30 \\
\hline $8^{\mathrm{d}}$ & 4- $\mathrm{BrC}_{6} \mathrm{H}_{4} \mathrm{CHO}$ & $\mathrm{C}_{6} \mathrm{H}_{5} \mathrm{~B}(\mathrm{OH})_{2}$ & 0.05 & $\mathrm{LiOH}(1 \mathrm{mmol})$ & Toluene/ $/ \mathrm{H}_{2} \mathrm{O}$ & $>99$ & 333 \\
\hline $9^{d}$ & 4- $\mathrm{BrC}_{6} \mathrm{H}_{4} \mathrm{NMe}_{2}$ & $\mathrm{C}_{6} \mathrm{H}_{5} \mathrm{~B}(\mathrm{OH})_{2}$ & 0.05 & $\mathrm{LiOH}(1 \mathrm{mmol})$ & Toluene/ $/ \mathrm{H}_{2} \mathrm{O}$ & 85 & 283 \\
\hline $10^{\mathrm{d}}$ & $4-\mathrm{BrC}_{6} \mathrm{H}_{4} \mathrm{OH}$ & $\mathrm{C}_{6} \mathrm{H}_{5} \mathrm{~B}(\mathrm{OH})_{2}$ & 0.05 & $\mathrm{LiOH}$ (2 mmol) & Toluene $/ \mathrm{H}_{2} \mathrm{O}$ & $>99$ & 333 \\
\hline $11^{\mathrm{d}}$ & $2-\mathrm{BrC}_{6} \mathrm{H}_{4} \mathrm{CHO}$ & $\mathrm{C}_{6} \mathrm{H}_{5} \mathrm{~B}(\mathrm{OH})_{2}$ & 0.5 & $\mathrm{LiOH}(1 \mathrm{mmol})$ & Toluene $/ \mathrm{H}_{2} \mathrm{O}$ & $>99$ & 333 \\
\hline $12^{\mathrm{d}}$ & $2-\mathrm{BrC}_{6} \mathrm{H}_{4} \mathrm{OMe}$ & $\mathrm{C}_{6} \mathrm{H}_{5} \mathrm{~B}(\mathrm{OH})_{2}$ & 0.5 & $\mathrm{LiOH}$ (1 mmol) & Toluene $/ \mathrm{H}_{2} \mathrm{O}$ & 18 & 6 \\
\hline $13^{\mathrm{d}}$ & 2-Bromopyridine & $\mathrm{C}_{6} \mathrm{H}_{5} \mathrm{~B}(\mathrm{OH})_{2}$ & 0.5 & $\mathrm{LiOH}$ (1 mmol) & Toluene $/ \mathrm{H}_{2} \mathrm{O}$ & 20 & 7 \\
\hline $14^{\mathrm{d}}$ & 4- $\mathrm{BrC}_{6} \mathrm{H}_{4} \mathrm{CHO}$ & $2,4,6-\mathrm{Me}_{3} \mathrm{C}_{6} \mathrm{H}_{2} \mathrm{~B}(\mathrm{OH})_{2}$ & 0.05 & $\mathrm{LiOH}(1 \mathrm{mmol})$ & Toluene $/ \mathrm{H}_{2} \mathrm{O}$ & 40 & 133 \\
\hline $15^{\mathrm{d}}$ & $2-\mathrm{BrC}_{6} \mathrm{H}_{4} \mathrm{CHO}$ & $2,4,6-\mathrm{Me}_{3} \mathrm{C}_{6} \mathrm{H}_{2} \mathrm{~B}(\mathrm{OH})_{2}$ & 0.5 & $\mathrm{LiOH}$ (1 mmol) & Toluene $/ \mathrm{H}_{2} \mathrm{O}$ & 51 & 17 \\
\hline $16^{\mathrm{d}, \mathrm{e}}$ & $4-\mathrm{ClC}_{6} \mathrm{H}_{4} \mathrm{CHO}$ & $\mathrm{C}_{6} \mathrm{H}_{5} \mathrm{~B}(\mathrm{OH})_{2}$ & 0.5 & $\mathrm{LiOH}(1 \mathrm{mmol})$ & Toluene $/ \mathrm{H}_{2} \mathrm{O}$ & 77 & 6 \\
\hline $17^{\mathrm{d}, \mathrm{e}}$ & $\mathrm{O}_{2} \mathrm{~N}$ & $\mathrm{C}_{6} \mathrm{H}_{5} \mathrm{~B}(\mathrm{OH})_{2}$ & 0.5 & LiOH (1 mmol) & Toluene $/ \mathrm{H}_{2} \mathrm{O}$ & 58 & 5 \\
\hline
\end{tabular}

\footnotetext{
a $\mathrm{Ar}-\mathrm{X}$ : $0.45 \mathrm{mmol}$; $\mathrm{ArB}(\mathrm{OH})_{2} 0.45 \mathrm{mmol}$ at $90^{\circ} \mathrm{C}$ for $6 \mathrm{~h}$.

${ }^{\mathrm{b}} \mathrm{GC}$ yield.

c TOF: turnover frequency: mol product/mol of catalyst $h$.

d Additive: $\mathrm{PPh}_{3}\left(4.5 \times 10^{-3} \mathrm{mmol}\right)$.

e Reaction time: $24 \mathrm{~h}$.
}

\subsubsection{Mechanistic pathway of catalysis}

Concerning the reaction pathway, we studied the course of the coupling reaction by monitoring the reaction mixture with ${ }^{1} \mathrm{H}$ NMR and TEM. Under the catalytic conditions, an aliquot from the reaction of the palladium complex with phenylboronic acid in the presence of base was examined by transmission electron microscopy, showing the formation of palladium particles with the diameter in the range of 5-20 $\mathrm{nm}$. Upon the addition of $p$-bromobenzaldehyde to the above solution, the coupling reaction underwent smoothly via checking the reaction mixture with NMR. This result suggests that the palladium nano-parti- cles might be responsible for this catalysis. It has been demonstrated that palladium nano-particles can catalyze the $\mathrm{C}-\mathrm{C}$ bond coupling reaction [17]. Although we can not completely exclude the homogeneous pathway, it is quite likely that the palladium nano-particles or clusters are the active species for the catalysis.

\section{Summary}

With this study we have demonstrated the versatility of pyridinyl-carbene ligand. By using carbene-transfer, palladium carbene complex $\left[C\right.$-(pyN $\left.\mathbf{N}^{\wedge} \mathbf{C}\right) \mathrm{Pd}(\pi$-allyl $\left.) \mathrm{Cl}\right](\mathbf{3})$ was

Table 5

Results of Mizoroki-Heck reaction catalyzed by $\mathbf{4}^{\mathrm{a}}$

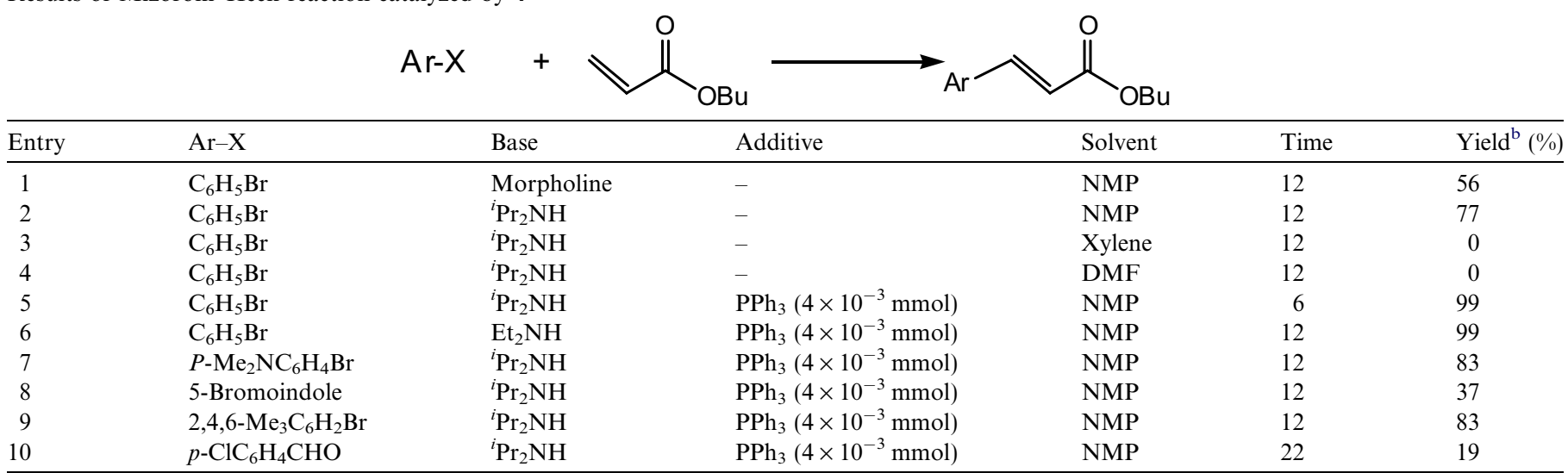

${ }^{\mathrm{a}}$ Reaction conditions: $\mathrm{ArX}(0.4 \mathrm{mmol})$; butyl acrylate $(0.48 \mathrm{mmol})$; Pd complex $\left(2 \times 10^{-3} \mathrm{mmol}\right)$ at $140{ }^{\circ} \mathrm{C}$.

${ }^{\mathrm{b}}$ GC yield. 
obtained via the reaction of the silver carbene complex $\mathbf{2}$ with $\left[\left(\eta^{3} \text {-allyl) } \mathrm{PdCl}\right]_{2}\right.$. Abstraction of chloride from $\mathbf{3}$ allowed to form the chelation of pyridinyl-carbene toward the metal center. This carbene chelating complex 4 decomposes in the presence of $t$-butoxide or hydrogen, but the palladium complexes obtained have shown good catalytic activity on Suzuki-Miyaura and Mizoroki-Heck reactions.

\section{Experimental}

\subsection{General}

All reactions and manipulations were performed under a dry nitrogen atmosphere unless otherwise noted. Tetrahydrofuran was distilled under nitrogen from sodium benzophenone ketyl. Dichloromethane was dried over $\mathrm{CaH}_{2}$ and distilled under nitrogen. Other solvents were degassed before use. Chemicals were purchased from commercial source and used without further purification. 1-(6-Mesityl-2-picolyl)-3-mesitylimidazolium bromide and its silver carbene complex were prepared according to the method reported easier [11].

Nuclear magnetic resonance spectra were recorded in $\mathrm{CDCl}_{3}$ or acetone- $d_{6}$ on either a Bruker AM-300 or AVANCE 400 spectrometer. Chemical shifts are given in parts per million relative to $\mathrm{Me}_{4} \mathrm{Si}$ for ${ }^{1} \mathrm{H}$ and ${ }^{13} \mathrm{C}\left\{{ }^{1} \mathrm{H}\right\}$ NMR, and relative to $85 \% \mathrm{H}_{3} \mathrm{PO}_{4}$ for ${ }^{31} \mathrm{P} \mathrm{NMR}$. Infrared spectra were measured on a Nicolet Magna-IR 550 spectrometer (Series-II) as KBr pallets, unless otherwise noted.

\subsection{Synthesis and characterization}

\subsection{1. [(C-py $\left.\boldsymbol{N}^{\wedge} \boldsymbol{C}\right) P d\left(\eta^{3}\right.$-allyl $\left.) C l\right](3)$}

A sample of $\left[\left(\eta^{3} \text {-allyl }\right) \mathrm{PdCl}\right]_{2}(100 \mathrm{mg}, 0.273 \mathrm{mmol})$ was dissolved in dichloromethane $(15 \mathrm{~mL})$ and silver carbene $\mathbf{2}$ (345 mg, $0.273 \mathrm{mmol}$ ) was added. The color of the solution changed immediately from colorless to yellow. The solution was stirred for $3 \mathrm{~h}$ at ambient temperature. The reaction mixture was filtered through Celite and the filtrate was concentrated. The residue was dissolved in dichloromethane/hexane and the desired complex was crystallized from the solution as a yellow solid $(217 \mathrm{mg}, 86 \%)$ : ${ }^{1} \mathrm{H}$ NMR (400 MHz, $\left.\mathrm{CDCl}_{3}\right): \delta 7.90(\mathrm{~d}, 1 \mathrm{H}, J=7.6 \mathrm{~Hz}, \mathrm{Py})$, 7.79 (dd, $1 \mathrm{H}, J=7.6 \mathrm{~Hz}, 7.6 \mathrm{~Hz}, \mathrm{Py}), 7.61$ (s, br, $1 \mathrm{H}$, Im), 7.18 (d, $1 \mathrm{H}, J=7.6 \mathrm{~Hz}, \mathrm{Py}), 6.92$ (s, 1H, Mes), 6.90 (s, $3 \mathrm{H}$, Mes), $6.83(\mathrm{~d}, 1 \mathrm{H}, J=2.0 \mathrm{~Hz}, \mathrm{Im}), 5.91(\mathrm{~d}, 1 \mathrm{H}$, $\left.J=14.8 \mathrm{~Hz}, \mathrm{CH}_{2}\right), 5.75\left(\mathrm{~d}, 1 \mathrm{H}, J=14.8 \mathrm{~Hz}, \mathrm{CH}_{2}\right), 4.89-$ $4.79(\mathrm{~m}, 1 \mathrm{H}$, allyl), 3.87 (d, 1H, $J=6.8 \mathrm{~Hz}$, allyl), 3.56 (s, br, $1 \mathrm{H}$, allyl), $2.94(\mathrm{~d}, 1 \mathrm{H}, J=6.8 \mathrm{~Hz}$, allyl), $2.69(\mathrm{~d}, 1 \mathrm{H}$, $J=14.0 \mathrm{~Hz}$, allyl), 2.30 (s, 6H, Me), 2.10 (s, 3H, Me), 1.96 (s, 6H, Me), 1.95 (s, 3H, Me) ${ }^{13} \mathrm{C}$ NMR $(100 \mathrm{MHz}$, $\left.\mathrm{CDCl}_{3}\right): \delta 179.7(\mathrm{Pd}=\mathrm{C}), \quad 160.0,155.7,138.8,137.9$, $137.7,137.6,136.1,135.6,135.5,135.0,129.0,128.7$, $128.3,124.6,122.8,122.1,115.3,77.5,73.0,56.4\left(\mathrm{CH}_{2}\right)$, 49.2, 21.8, 21.1, 19.0, 18.7. HR-FAB for $[\mathrm{M}-\mathrm{Cl}]^{+}$: Calc. $542.1788\left(\mathrm{C}_{30} \mathrm{H}_{34} \mathrm{~N}_{3}{ }^{106} \mathrm{Pd}\right)$, found: 542.1779. Anal. Calc. for $\mathrm{C}_{30} \mathrm{H}_{34} \mathrm{~N}_{3} \mathrm{ClPd}$ : $\mathrm{C}, 62.29 ; \mathrm{H}, 5.92 ; \mathrm{N}, 7.26$. Found: $\mathrm{C}$, $62.18 ; \mathrm{H}, 5.90 ; \mathrm{N}, 7.06 \%$.

\subsection{2. $\left[\left(C, N-p y N^{\wedge} C\right) P d\left(\eta^{3}-\right.\right.$ allyl $\left.)\right] B F_{4}(4)$}

A sample of $3(89 \mathrm{mg}, 0.15 \mathrm{mmol})$ was dissolved in $10 \mathrm{~mL}$ of dichloromethane and $\mathrm{AgBF}_{4}(30 \mathrm{mg}, 0.15 \mathrm{mmol})$ was added. The mixture was stirred for $2 \mathrm{~h}$ at ambient temperature. The reaction mixture was filtered through Celite and the filtrate was added to a solution of hexane $(10 \mathrm{~mL})$ to yield the white precipitates. Upon filtration, the desired complex was obtained white powders $(85 \mathrm{mg}$, $88 \%$ ). Recrystallization from acetone/hexane gave complex 4 as a colorless crystalline solid. ${ }^{1} \mathrm{H}$ NMR $\left(\mathrm{CDCl}_{3}\right.$, $\left.400 \mathrm{MHz}, 50^{\circ} \mathrm{C}\right): \delta 8.20(\mathrm{dd}, 1 \mathrm{H}, J=7.6 \mathrm{~Hz}, 1.2 \mathrm{~Hz}, \mathrm{Py})$, $8.03(\mathrm{dd}, 1 \mathrm{H}, J=7.6 \mathrm{~Hz}, 7.6 \mathrm{~Hz}, \mathrm{Py}), 7.99(\mathrm{~d}, 1 \mathrm{H}$, $J=1.6 \mathrm{~Hz}, \mathrm{Im}), 7.34(\mathrm{dd}, 1 \mathrm{H}, J=7.6 \mathrm{~Hz}, 1.2 \mathrm{~Hz}, \mathrm{Py})$, 6.95 (s, br, 2H, Mes), 6.89 (s, br, 2H, Mes), 6.84 (d, 1H, $J=1.6 \mathrm{~Hz}, \mathrm{Im}), 5.81\left(\mathrm{~d}, 1 \mathrm{H}, J=14.4 \mathrm{~Hz}, \mathrm{CH}_{2}\right), 5.60(\mathrm{br}$, $\left.1 \mathrm{H}, \mathrm{CH}_{2}\right), 4.76(\mathrm{br}, 1 \mathrm{H}$, allyl), $3.34(\mathrm{~d}, 1 \mathrm{H}, J=6.8 \mathrm{~Hz}$, allyl), 2.83 (s, br, 1H, allyl), 2.33 (s, 3H, Me), 2.29 (s, 3H, $\mathrm{Me}), 1.97$ (s, 3H, Me), $1.93(\mathrm{~s}, 6 \mathrm{H}, \mathrm{Me}), 1.88$ (s, 3H, $\mathrm{Me}), 1.82\left(\mathrm{~d}, 1 \mathrm{H}, J=12.0 \mathrm{~Hz}\right.$, allyl). ${ }^{13} \mathrm{C}$ NMR $\left(\mathrm{CDCl}_{3}\right.$, $\left.100 \mathrm{MHz}, 50^{\circ} \mathrm{C}\right): \delta 176.3(\mathrm{Pd}=\mathrm{C}), 162.1,155.1,140.3$, $139.6,139.4,138.6,136.2,135.8,135.2,135.0,129.1$, $128.4,126.9,126.8,125.4,124.0,123.9,122.6,117.4,55.6$ $\left(\mathrm{CH}_{2}\right)$, 21.0, 20.9, 20.7, 17.7, 17.6. Anal. Calc. for $\mathrm{C}_{30} \mathrm{H}_{34} \mathrm{BF}_{4} \mathrm{~N}_{3} \mathrm{Pd}: \mathrm{C}, 57.21 ; \mathrm{H}, 5.44 ; \mathrm{N}, 6.67$. Found: $\mathrm{C}$, $57.15 ; \mathrm{H}, 5.09 ; \mathrm{N}, 6.24 \%$.

\subsection{3. $\left(C-p y N^{\wedge} C\right) P d\left(\eta^{3}\right.$-allyl) $\left(P P h_{3}\right)($ 5)}

A flame dried Schlenk flask was charged with $[(C, N$ $\left.\mathbf{p y N}^{\wedge} \mathbf{C}\right) \operatorname{Pd}\left(\eta^{3}\right.$-allyl $\left.)\right] \mathrm{BF}_{4}(17.7 \mathrm{mg}, 0.028 \mathrm{mmol})$ in dichloromethane $(2 \mathrm{~mL})$. A solution of $\mathrm{PPh}_{3}(7.4 \mathrm{mg}$, $0.028 \mathrm{mmol})$ in chloromethane $(2 \mathrm{~mL})$ was added via cannula and stirred at room temperature. After $\sim 30 \mathrm{~min}$, the desired complex precipitated from the solution. The product was isolated by filtration, washed with hexane $(1 \mathrm{~mL} \times 2)$ and dried under vacuum at room temperature for $2 \mathrm{~h}$. A light yellow solid was collected $(24.9 \mathrm{mg}, 99 \%)$ : ${ }^{1} \mathrm{H}$ NMR $\left(400 \mathrm{MHz}, \mathrm{CDCl}_{3}\right): \delta 7.81(\mathrm{br}, 1 \mathrm{H}), 7.65-6.88$ $(\mathrm{m}, 22 \mathrm{H}), 6.76(\mathrm{~s}, 1 \mathrm{H}), 5.12-5.08(\mathrm{br}, 1 \mathrm{H}), 4.86(\mathrm{~d}, 1 \mathrm{H}$, $J=14.0 \mathrm{~Hz}), 4.81$ (br, 1H), $3.90(\mathrm{br}, 1 \mathrm{H}), 3.56(\mathrm{~m}, 1 \mathrm{H})$, $2.50(\mathrm{~d}, 1 \mathrm{H}, J=13.2 \mathrm{~Hz}), 2.29(\mathrm{~s}, 6 \mathrm{H}), 2.22-2.20(\mathrm{~m}, 1 \mathrm{H})$, $1.90(\mathrm{~s}, 6 \mathrm{H}), 1.72(\mathrm{~s}, 3 \mathrm{H}), 1.45(\mathrm{~s}, 3 \mathrm{H})$ (major); $7.81(\mathrm{br}$, $1 \mathrm{H}), 7.65-6.88(\mathrm{~m}, 22 \mathrm{H}), 6.63(\mathrm{~s}, 1 \mathrm{H}), 5.12-5.08(\mathrm{br}, 1 \mathrm{H})$, $4.81(\mathrm{br}, 1 \mathrm{H}), 4.66(\mathrm{~d}, 1 \mathrm{H}, J=14.0 \mathrm{~Hz}), 3.90(\mathrm{br}, 1 \mathrm{H})$, $3.46(\mathrm{~d}, 1 \mathrm{H}, J=6.0 \mathrm{~Hz}), 2.63(\mathrm{~m}, 1 \mathrm{H}), 2.31(\mathrm{~s}, 6 \mathrm{H}), 2.17$ $(\mathrm{m}, 1 \mathrm{H}), 1.90(\mathrm{~s}, 6 \mathrm{H}), 1.78(\mathrm{~s}, 3 \mathrm{H}), 1.36(\mathrm{~s}, 3 \mathrm{H})$ (minor). ${ }^{31} \mathrm{P}$ NMR (121.4 MHz, $\mathrm{CDCl}_{3}$ ): $\delta 23.9$ (major); 24.7 (minor). ${ }^{13} \mathrm{C}$ NMR $\left(100 \mathrm{MHz}, \mathrm{CDCl}_{3}\right): \delta 177.6\left(\mathrm{~d}, J_{\mathrm{P}-}\right.$ $\mathrm{C}=16.2 \mathrm{~Hz}), 158.9,154.0,71.3$ (allyl), 68.3 (allyl), 67.6 (d, $J=29.7 \mathrm{~Hz}$, allyl $), 55.9\left(\mathrm{CH}_{2}\right), 21.5,21.4,20.5,18.1,17.9$ (major); $177.6\left(\mathrm{~d}, J_{\mathrm{P}-\mathrm{C}}=16.2 \mathrm{~Hz}\right), 158.9,154.3,71.3$ (allyl), 70.2 (d, $J=27.4 \mathrm{~Hz}$ ), 68.3 (allyl), 21.5, 21.4, 20.5, 18.3, 18.1 (minor). Anal. Calc. for $\mathrm{C}_{48} \mathrm{H}_{49} \mathrm{~N}_{3} \mathrm{BF}_{4} \mathrm{PPd}$ : C, 64.62; H, 5.54; N, 4.71. Found: C, 64.89; H, 5.94; N, 4.44\%. 


\subsubsection{Decomposition of $\left(C-p y N^{\wedge} C\right) P d\left(\eta^{3}\right.$-allyl $) C l$ in the presence of $\mathrm{HBF}_{4}$}

To a flask was placed with $3\left(5.8 \mathrm{mg}, 1.0 \times 10^{-3} \mathrm{mmol}\right)$. The flask was evacuated and filled with nitrogen gas. $\mathrm{CDCl}_{3}(2 \mathrm{~mL})$ and $\mathrm{HBF}_{4}$ were then added and the resulted solution was stirred at $50{ }^{\circ} \mathrm{C}$ for $10 \mathrm{~h}$. The reaction mixture was filtrated through Celite and the filtrate was concentrated to give 1-(6-mesityl-2-picolyl)-3-mesitylimidazolium tetrafluoroborate $(4.0 \mathrm{mg}, 83 \%) .{ }^{1} \mathrm{H}$ NMR $(400 \mathrm{MHz}$, $\left.\mathrm{CDCl}_{3}\right): \delta 8.91(\mathrm{~s}, 1 \mathrm{H}, \mathrm{Im}-\mathrm{H} 2), 7.82-7.78(\mathrm{~m}, 2 \mathrm{H}), 7.62$ $(\mathrm{d}, 1 \mathrm{H}, J=7.6 \mathrm{~Hz}, P y), 7.17(\mathrm{~d}, 1 \mathrm{H}, J=7.6 \mathrm{~Hz}, P y)$, 7.09 (m, 1H), 6.93 (s, 2H, Mes), 6.87 (s, 2H, Mes), 5,78 $\left(\mathrm{s}, 2 \mathrm{H}, \mathrm{CH}_{2}\right), 2.29(\mathrm{~s}, 6 \mathrm{H}, \mathrm{Me}), 1.87(\mathrm{~s}, 12 \mathrm{H}, \mathrm{Me}) \cdot{ }^{13} \mathrm{C}$ NMR $\left(100 \mathrm{MHz}, \mathrm{CDCl}_{3}\right): \delta 160.2,152.1,141.2,138.0$, $137.7,137.1,135.4,134.5,130.6,129.7,128.3,124.9$, 124.0, 122.8, 121.3, 54.2 ( $\left.\mathrm{CH}_{2}\right), 21.0,20.1,16.9$. Anal. Calc. for $\mathrm{C}_{27} \mathrm{H}_{30} \mathrm{~N}_{3} \mathrm{BF}_{4}$ : C, 67.09; $\mathrm{H}, 6.26 ; \mathrm{N}, 8.69$. Found: $\mathrm{C}$, 66.69; H, 6.26; N, 8.48\%.

\subsubsection{Decomposition of 5 in the presence of air}

Complex 5 ( $8.9 \mathrm{mg}, 0.01 \mathrm{mmol})$ was placed into a $2 \mathrm{~mL}$ flask and $\mathrm{CDCl}_{3}(2 \mathrm{~mL})$ was added. The mixture was stirred in air for $72 \mathrm{~h} .{ }^{1} \mathrm{H}$ NMR and ${ }^{31} \mathrm{P}$ NMR spectra of the resulting mixture were taken. Besides the aromatic region, the characteristic shifts for complex $\mathbf{4}$ appeared in the ${ }^{1} \mathrm{H}$ NMR spectrum. For ${ }^{31} \mathrm{P}$ NMR spectrum, only one signal at $\delta 28.4$ appeared, which was identical to the authentic sample of triphenylphosphine oxide. Upon crystallization, complex 4 was obtained (4.7 mg, 74\%). Extraction of the residue with hexanes followed by concentration gave a white solid (1.2 mg), which was identified as triphenylphosphine oxide.

\subsection{X-ray crystallographic analysis}

Crystals suitable for X-ray determination were obtained for by recrystallization at room temperature. Cell parameters were determined either by a Nonius Kappa CCD diffractometer. Crystal data of 4: $\mathrm{C}_{30} \mathrm{H}_{34} \mathrm{BF}_{4} \mathrm{~N}_{3} \mathrm{Pd}, \mathrm{Fw}=$ 629.81, monoclinic, $P 2_{1} / c, a=9.6413(1) \AA, b=24.7392(4)$ $\AA, c=12.3674(2) \AA, \alpha=90^{\circ}, \beta=95.1790(8){ }^{\circ}, \gamma=90^{\circ}$, $V=2937.81(7) \AA^{3}, Z=4, D_{\text {calc }}=1.424 \mathrm{Mg} / \mathrm{m}^{3}, F(000)=$ $1288, \quad 0.30 \times 0.20 \times 0.15 \mathrm{~mm}, \quad \theta \quad$ range $=21.65-27.49^{\circ}$, 6730 independent reflections $\left(\mathrm{R}_{\text {int }}=0.0283\right)$ out of 19092 reflections collected, full-matrix least square on $F^{2}, R_{1}=$ $0.0473, w R_{2}=0.1346[I>2 \sigma(I)]$, Goodness-of-fit on $F^{2}$ 1.134. Other crystallographic data are deposited as supporting information.

\section{Supplementary material}

CCDC 642829 contains the supplementary crystallographic data for 4. These data can be obtained free of charge via http://www.ccdc.cam.ac.uk/conts/retrieving. html, or from the Cambridge Crystallographic Data Centre, 12 Union Road, Cambridge CB2 1EZ, UK; fax: (+44) 1223-336-033; or e-mail: deposit@ccdc.cam.ac.uk.

\section{Acknowledgement}

We thank the National Science Council, Taiwan, ROC for the financial support (NSC95-2113-M-002-038).

\section{References}

[1] A.J. Arduengo III, R.L. Harlow, M. Kline, J. Am. Chem. Soc. 113 (1991) 361

[2] (a) M. Regitz, Angew. Chem., Int. Ed. Engl. 35 (1996) 725;

(b) L. Delaude, A. Demonceau, A.F. Noels, Curr. Org. Chem. 10 (2006) 203;

(c) S.-T. Liu, K.R. Reddy, Chem. Soc. Rev. 28 (1999) 315;

(d) C.M. Crudden, D.P. Allen, Coord. Chem. Rev. 248 (2004) 2247;

(e) D. Bourissou, O. Guerret, F. Gabbaï, G. Bertrand, Chem. Rev. $100(2000) 39$.

[3] A.J. Arduengo III, J.R. Goerlich, W.J. Marshall, J. Am. Chem. Soc. 117 (1995) 11027.

[4] (a) R.W. Alder, P.R. Allen, M. Murray, A.G. Orpen, Angew. Chem., Int. Ed. Engl. 35 (1996) 1121;

(b) R.W. Alder, C.P. Butts, A.G. Orpen, J. Am. Chem. Soc. 120 (1998) 11526.

[5] (a) W.A. Herrmann, M. Elison, J. Fischer, C. Köcher, G.R.J. Artus, Chem. Eur. J. 2 (1996) 772;

(b) W.A. Herrmann, C. Köcher, Angew. Chem., Int. Ed. Engl. 36 (1997) 2162;

(c) W.A. Herrmann, L.J. Goossen, M. Spiegler, Organometallics 17 (1998) 2162;

(d) M.J. Green, K.J. Cavell, B.W. Skelton, A.H. White, J. Organomet. Chem. 554 (1998) 175

[6] (a) D.S. McGuinness, K.J. Cavell, Organometallics 19 (2000) 741;

(b) A.A. Danopoulos, S. Winston, M.B. Hursthouse, J. Chem. Soc., Dalton Trans. (2002) 3090;

(c) N.M. Scott, R. Dorta, E.D. Stevens, A. Correa, L. Cavallo, S.P. Nolan, J. Am. Chem. Soc. 127 (2005) 3516

[7] (a) S.A. Mungur, S.T. Liddle, C. Wilson, M.J. Sarsfield, P.L. Arnold, Chem. Commun. (2004) 2738;

(b) L.G. Bonnet, R.E. Douthwaite, Organometallics 22 (2003) 4187; (c) A.A.D. Tulloch, A.A. Danopoulos, R.P. Tooze, S.M. Cafferkey, S. Kleinhenz, M.B. Hursthouse, Chem. Commun. (2000) 1247;

(d) S. Gründemann, A. Kovacevic, M. Albrecht, J.W. Faller, R.H. Crabtree, Chem. Commun. (2001) 2274;

(e) S. Gründemann, A. Kovacevic, M. Albrecht, J.W. Faller, R.H. Crabtree, J. Am. Chem. Soc. 124 (2002) 10473;

(f) S. Dastgir, K.S. Coleman, A.R. Cowley, M.L.H. Green, Organometallics 25 (2006) 300;

(g) K.S. Coleman, H.T. Chamberlayne, S. Turberville, M.L.H. Green, A.R. Cowley, Dalton Trans. (2003) 2917;

(h) L.G. Bonnet, R.E. Douthwaite, R. Hodgson, J. Houghton, B.M. Kariuki, S. Simonovic, Dalton Trans. (2004) 3528.

[8] (a) A.A. Danopoulos, S. Winston, T. Gelbrich, M.B. Hursthouse, R.P. Tooze, Chem. Commun. (2002) 482;

(b) N. Tsoureas, A.A. Danopoulos, A.A.D. Tulloch, M.E. Light, Organometallics 22 (2003) 4750;

(c) H.M. Lee, P.L. Chiu, J.Y. Zeng, Inorg. Chim. Acta 357 (2004) 4313;

(d) S. Gischig, A. Togni, Organometallics 24 (2005) 203.

[9] (a) A.W. Waltman, R.H. Grubbs, Organometallics 23 (2004) 3105;

(b) P.L. Arnold, M. Rodden, K.M. Davis, A.C. Scarisbrick, A.J. Blake, C. Wilson, Chem. Commun. (2004) 1612;

(c) P.L. Arnold, A.C. Scarisbrick, Organometallics 23 (2004) 2519;

(d) A.R. Chianese, R.H. Crabtree, Organometallics 24 (2005) 4432;

(e) B.E. Ketz, A.P. Cole, R.M. Waymouth, Organometallics 23 (2004) 2835;

(f) E. Mas-Marzá, M. Sanaú, E. Peris, Inorg. Chem. 44 (2005) 9961.

[10] (a) C. Köcher, W.A. Herrmann, J. Organomet. Chem. 532 (1997) 261 
(b) S.-T. Liu, T.-Y. Hsieh, G.-H. Lee, S.-M. Peng, Organometallics 17 (1998) 993;

(c) R.-Z. Ku, J.-C. Huang, J.-Y. Cho, F.-M. Kiang, K.R. Reddy, Y.-C. Chen, K.-J. Lee, J.-H. Lee, G.-H. Lee, S.-M. Peng, S.-T. Liu, Organometallics 18 (1999) 2145;

(d) K.H. Park, S.Y. Kim, S.U. Son, Y.K. Chung, Eur. J. Org. Chem. (2003) 4341;

(e) K.L. Tan, R.G. Bergman, J.A. Ellman, J. Am. Chem. Soc. 124 (2002) 3202;

(f) M.T. Zarka, M. Bortenschlager, K. Wurst, O. Nuyken, R. Weberskirch, Organometallics 23 (2004) 4817;

(g) R. Dorta, E.D. Stevens, S.P. Nolan, J. Am. Chem. Soc. 126 (2004) 5054;

(h) V. César, S. Bellemin-Laponnaz, H. Wadepohl, L.H. Gade, Chem. Eur. J. 11 (2005) 2862.
[11] C.-Y. Wang, Y.-H. Liu, S.-M. Peng, S.-T. Liu, J. Organomet. Chem. 691 (2006) 4012.

[12] S. Caddick, F.G.N. Cloke, G.K.B. Clentsmith, P.B. Hitchcock, D. McKerrecher, L.R. Titcomb, M.R.V. Williams, J. Organomet. Chem. 617-618 (2001) 635.

[13] M.S. Viciu, F.K. Zinn, E.D. Stevens, S.P. Nolan, Organometallics 22 (2003) 3175.

[14] B.E. Ketz, A.P. Cole, R.M. Waymouth, Organometallics 23 (2004) 2835.

[15] M.S. Viciu, O. Navarro, R.F. Germaneau, R.A. Kelly III, W. Sommer, N. Marion, E.D. Stevens, L. Cavallo, S.P. Nolan, Organometallics 23 (2004) 1629.

[16] S.U. Son, Y. Jang, K.Y. Yoon, E. Kang, T. Hyeon, Nano Lett. 4 (2004) 1147.

[17] M.T. Reetz, J.G. de Vries, Chem. Commun. (2004) 1959. 